\title{
Unions in Medieval Church Law as the Basis for Description of the Legal Nature of the Polish-Litbuanian Union
}

\begin{abstract}
In church law, the union of churches (unio ecclesiarum) concerned the merger of two and more dioceses under the same bishop. In the Middle Ages, canonists were already pointing to three types of union: 1) aeque principalis; 2) unio per subiectionem, when one of the churches was subject to the other and thus the episcopal dignity remained only in that one, and finally, the third kind, called 3) unio per extinctionem, when two particular churches, usually dioceses, were merged into a single new one. The canonical achievements in the field of union of churches and benefices were collected and summarized, among others, in the treatise De unionibus ecclesiarum atque beneficiorum by Nicolaus Thilen, and in the work of Anaclet Reiffenstuel entitled Ius canonicum universum. The three types of union of churches and benefices presented above, distinguished by their mergers, were adopted into the Code of Canon Law of 1917 (canons 1419 and 1420). The 450th anniversary of the union concluded on July 1, 1569 in Lublin was celebrated in 2019. As a result of this union the Kingdom of Poland, called the Crown, merged with the Grand Duchy of Lithuania. The canonical models of the union of churches and benefices, developed in medieval canon law, are important for a closer description of the essence of this relationship, starting with the first of them, i.e. the union concluded in 1385 in Krevo. The political relationships established between the Kingdom of Poland and the Grand Duchy of Lithuania largely corresponded to the three canonical models of the church union indicated above, i.e. unio aeque principalis (1385), unio per subiectionem (1413) and unio per extinctionem seu translationem (1569).
\end{abstract}

Keywords: history of Poland, history of canon law, union of churches and benefices, unio ecclesiarum, Polish-Lithuanian union

Słowa kluczowe: historia Polski, historia prawa kanonicznego, unia kościołów i beneficjów, unio ecclesiarum, unia polsko-litewska

The purpose of the study is to present the concept of a union of legal entities, in particular churches (unio ecclesiarum), ${ }^{1}$ educated in the doctrine of canon law in the Middle Ages and the modern age, and draw attention to its usefulness for explaining the

${ }^{1}$ Hinschius, System, 417-55; Herman, “Sjedinjenje biskupija”, 91; Hofmeister, "Die Doppeltitel”, 2278; Knibbs, Ansgar, 157; Lindner, Die Lehre, 47-54, 77-8; Scholz, Das Bistum, 130. See also: Durand de Maillane, Dictionnaire, 509-16. 
legal nature of the political relationship of the Polish Kingdom and the Grand Duchy of Lithuania in the period from the fourteenth to the sixteenth century.

Only the medieval church law of the Roman Catholic Church used the notion of a union, which it used to regulate the issues of uniting churches or benefices. No other law known in the Middle Ages knew such a concept, neither Roman nor feudal law, nor any national law, such as German or Polish. ${ }^{2}$ In church law, the union of churches (unio ecclesiarum) involved uniting two or more dioceses under the same bishop. This issue was addressed in Gratian's Decretum in a gloss to verbum Unire present in the C. 16 q. 1 c. 48 Et temporis canon, At the general level, this canon concerned uniting bishoprics (unio plurium episcopatuum). In the gloss, Bartholomew of Brescia (Bartholomeus Brixiensis, 1200-1258) - the glossator - raised very important issues related to the topic of mutual relations between united bishoprics. In particular, he asked which of the churches would retain its episcopal dignity (dignitas episcopalis) or whether both would retain their previous dignity after uniting (apud quam istarum ecclesiarum resideat dignitas episcopalis, vel an utraeque retineant dignitatem priorem). ${ }^{3}$ The answer to this question depended on what kind of church union a particular case involved. According to the glossator, churches could be united in three ways.

In the first type of union, one of the churches was subordinate to the other and thus the episcopal dignity remained only in one of them (una subiiciatur alteri et secundum hoc dignitas episcopalis erit in una tantum).

The second type of union involved uniting two dignities into one. Thus, in place of two separate dignities, one arose and instead of two separate churches, one was formed (ex duabus dignitatibus una fiat dignitas et secundum hoc non dicentur esse duae ecclesiae, sed una tantum).

In the third type of union, both united churches remained bishoprics, under the rule of the same bishop (idem sit episcopus utriusque ecclesiae).

These three ways of forming a union of particular churches (bishoprics) were also identified by Bernardus de Botone Parmensis 4 in his gloss to the Decretals of Gregory IX, specifically in the gloss to X. 3, 9, 1, v. Uniendo. This gloss was not original, rather it reiterated opinions expressed in the gloss to the Decretum of Gratian by Bartholomew of Brescia. Similarly, three types or ways of uniting bishoprics were distinguished. The first concerned a union by subordinating (subiicere) one church to another church. As a result of this type of union, the bishop's throne was in the superior diocese (hoc erit sedes apud illam cui subiicitur). ${ }^{5}$

The second type of church union mentioned by the glossator was one which consisted in merging two churches into one (ex duabus dignitatibus fiat una). The third type took place by subordinating two bishoprics, which retained their dignity (dignitas), i.e. they remained separate bishoprics but were under the authority of the same bishop.

In the gloss to Gratian's Decretum, the second type of church union, the merging of churches was considered in detail. In such a case, the glossator wrote, the canons of one bishopric became canons in the other and jointly participated in the election of the

\footnotetext{
2 The issue of union in church law was discussed in Uruszczak's work titled Unio regnorum, passim.

3 Decretum Gratiani emendatum, col. 1114.

4 Bernardus de Botone Parmensis, c. 1200-1263. Schulte, Die Geschichte, Bd. 1, 114.

5 Decretales Gregorii Papae IX, 776, glossa ad X. 3, 9, 1, v. Uniendo.
} 
bishop, as well as in managing common affairs. However, in this type of uniting (union) of bishoprics, the glossator distinguished two cases: when two churches join together (ecclesiae simul uniuntur) and when one church is joined to another, significantly different church (una earum unitur reliquae, quae duo sunt penitus diversa). In the latter case, the customs and laws of the united churches, in particular, the better and more humane ones, still remain in force. ${ }^{6}$

The issues pertaining to the union of churches and benefices were discussed by the French canonist, Petrus Rebuffus (Pierre Rebuffe, Pierre Rebuffi, 1487-1557) professor of the University of Montpellier in the work entitled Praxis beneficiorum. ${ }^{7}$ By the concept of union he understood the amalgamation (annexio) of benefices or churches made by the bishop or other superior (Unio est beneficiorum seu ecclesiarum ab episcopo vel ab alio superiore facta annexio) ${ }^{8}$ According to him, the canonical regulations concerning the union of benefices fully pertained to the union of churches, i.e. essentially bishoprics. In his work, we read: Etiam dico beneficiorum seu ecclesiarum, quia beneficium est terminus generalis omnia comprehendens beneficia, maiora vel minora, regularia et saecularia, dignitates et personatus, ac officia [...]. ${ }^{9}$ According to his position, the union of benefices also concerned the union of bishoprics [duo episcopates uniri possunt. ca.decimas et seq. 16.q.1].

Rebuffi distinguished temporal unions (unio temporalis) and perpetual unions (unio perpetua). The first of these was usually a lifetime union, valid for the life of the entitled person (ad vitam eius, cui conceditur). The perpetual union took place when the documents stated that it was "for perpetual memory" (ad perpetuam memoriam), or when it was made "by papal consent" (ad bene placitum sedis apostolicae). ${ }^{10}$

According to the French canonist, a union was formed in one of three ways.

The first involved merging two benefices into one. As an example, he gave the merger of two bishoprics into one bishopric by the Pope. As a result of such a merger of two into one (una fiat ex duabus), the privileges that were once exercised in one bishopric were fully valid in the new one.

The second way of establishing the union was when one church became subordinate to another. One of the churches forming the union became a superior church (superior et principalis). The attached church, on the other hand, became subordinate (unita vero erit inferior et accessoria).

The third type of union was by the appointment of a single bishop for both united churches or the same rector for each of the benefices so united.

Tertio fit unio duarum ecclesiarum, ut utraque remanent episcopatus, vel parochialis, sicut erat, et tunc dicitur aeque principalis utraque ecclesia, sed unus erit episcopus, vel rector utriusque eccle-

${ }^{6}$ In tali unione distinguendum credo, quo aut ecclesiae simul uniuntur, aut una earum unitur reliquae, quae duo sunt penitus diversa. Si una unitur alteri, secundum hoc illius naturam et consuetudinem et privilegium assumit cui unitur: et peribunt iura illius ecclesiae quae unitur, ut extr. de ista. mon. recolentes. circa fi. Si autem neutra alteri unitur, sed illae simul uniuntur, tunc dico quod consuetudines vel privilegia quae meliora sunt et humaniora, detinet illud unitum, nam cum malum et bonum associantur, malum recipit naturam boni. 32. Q. 1. Non est culpandus et ar.C. de rei. uxo.act. in prin. et C. com. de le. 1.2. c. fin. (Decretum Gratiani).

7 Praxis Beneficiorum D. Petri Rebuffi, 136.

8 Ibid., 136.

9 Ibid.

${ }^{10}$ Ibid., 137. 
siae, et tunc quaelibet sua habebit privilegia et statuta. gl. et doct. in c. et temporis. 16.q.1. Bartol. et alii in 1. si convenerit. §. si nuda. ff. de pign. actio. ${ }^{11}$

The three ways of forming a union of churches and benefices were not the only ones considered within studies in canon law. The thirteenth century decretalist, Henricus de Segusio, known as Hostiensis (c. 1200-1271) presented five such ways in his Summa Decretalium. ${ }^{12}$ The first consisted in the joint performance of clerical services (spiritualia communicentur) by several cathedral churches or monasteries. The second way involved subordinating one church to another in priestly and worldly matters, whereby one church became the mother (mater) and the other one the daughter (filia). ${ }^{13}$ In the third case, none of the churches was subordinate to another, but after the union was concluded they maintained their current status; however, they reported to one bishop chosen in the place agreed by the canons from both dioceses. The fourth way was to create one community from both churches - a collegium (unum sit collegium utriusque ecclesiae), whereas the fifth was when a church was raised to the status of a cathedral and the same bishop retained authority over it (Quinto modo sic fiet unio, altera cathedralis erigatur et unus sit duarum episcopus $){ }^{14}$

Hostiensis's position on the five ways of forming a union of churches and benefices was shared by other canonists, authors of separate treatises devoted solely to the issue of church unions, such as Petrus Perusinus ${ }^{15}$ or Johannes Baptista Cacialupus. However, these views were met with criticism. Arguing with Petrus de Perusio, Johannes de Lignano (1320-1383) objected to recognizing the first way indicated by Hostiensis as a union of churches. In his opinion, this was about the joint performance of clerical services (communicatio spiritualium), not about a union. There was also no union of churches in the fifth indicated case, when one of the churches in the diocese was raised to the rank of a cathedral, and the authority was exercised by the same bishop. This is because, in this case, there was a change in the status of the church; moreover, the case could be included in the third way of forming a union of churches indicated by Hostiensis. This is the situation in which two churches were under the authority of one bishop.

The methods of uniting churches set out above became the basis for the Italian canonist Johannes Baptista Caccialupus (1420-1496) to formulate the following definition of the union of churches (unio ecclesiarum):

Unio est coniunctio siue congregatio duarum aut plurium ecclesiarum vel per viam subiectionis, vel per viam aequalitatis aut accessionis seu erectionis quo ad spiritualia vel temporalia vel quo ad utrumque quandoque quo ad ecclesias tantum quandoque quo ad praelatos, quandoque quo ad utrosque. ${ }^{16}$

[Union consists in uniting or merging two or more churches either by means of subordination (per viam subiectionis), or by means of equality (per viam aequalitatis), accession

\footnotetext{
11 Ibid.

12 Henrici a Segusio Cardinalis Hostiensis Aurea Summa, col. 797-8.

13 Secundo unitur sit una ecclesia alteri, ut ei subiiciatur in spiritualibus et temporalibus, ita quod una sit mater altera filia (Henrici a Segusio Cardinalis Hostiensis Aurea Summa, col. 797).

14 Ibid.

15 Petrus de Ubaldis, called Perusinus (1335-1400). Schulte, Die Geschichte, Bd. 2, 277-8.

16 Cacialupus, De unionibus, 2.
} 
(accessio) or foundation (erectio), regarding spiritual or worldly matters, sometimes for these churches, sometimes for their prelates or sometimes for both.]

Alphonsus Hoieda de Mendoza, a sixteenth-century Spanish canonist and the author of the treatise De beneficiorum incompatibilitate atque comptabilitate ${ }^{17}$, for the most part reiterated Pierre Rebuffi's statement. An original feature of Hoieda's text were clarifications regarding the terminology used in the documents for the designation of acts of union. The considerations on this subject are particularly interesting. They concerned the following terms: unio, annexio, incorporatio, suppressio, extinctio, applicatio, dismembratio. In terms of meaning, each concerns a particular aspect of the union of churches or benefices. First of all, the terms such as suppressio, extinctio, et dismembratio, that is dissolution, termination and separation are fundamentally different from the terms such as annexio, incorporatio and applicatio. In particular, dismembratio (separation) is clearly distinguished from the last three. ${ }^{18}$

According to Hoieda, the term union (unio) has a general meaning and covers various types of uniting churches. A union is a generic name (genus), which covers all other cases of union, treated as its individual types (species). Dissolution (suppressio) and termination (extinctio) of a benefice or church are consequences of a union. This takes place in the first and second cases of the union, that is when two or more bishoprics or other churches or benefices are united to form a new one. The case is similar when the union consists in subordinating one church or benefice to another. In such cases, the benefice or church in its original form is terminated and dissolved.

Amalgamation (annexio), attachment (applicatio), subordination (subiectio) and incorporation (incorporatio) are types of union. Amalgamation and attachment unite churches or benefices more loosely than subordination (subiectio). This occurs when a church united with another retains its rights and distinctiveness. This is the case when the union is formed by the third method (personal union). Incorporation, on the other hand, is the broadest term and means the emergence of a new organism from the union (corpus), where common laws apply. In support of his position, the Spanish lawyer referred to the authority of the famous lawyers such as Bartolus de Saxoferrato (13131357), Baldus de Ubaldis (1327-1400) and Felinus (Felino Maria Sandeo, 1444-1503), as well as Consilium 114 by Alexander de Imola (1424-1477). ${ }^{19}$ According to Alphonsus Hoieda, the term dismembratio refers to a situation where a church or benefice had already been separated before the union or when the union is to be dissolved. ${ }^{20}$

17 Alphonsi Hoieda ... tractatus. Cf. De Dios, "La doctrina", 241-70.

${ }^{18}$ [p. 115a] Tertio praemittendum erit, quod sunt plura nomina,quae idem uidentur significare, scilicet unio, annexio, incorporatio, suppressio, extinctio, applicatio, dismembratio.Tamen diuersa sunt: quia nominum diuersitas inducit diuersitatem rerum, et nomina debent conuenire rebus: ut probarut in 1. si idem C. de codicillis, in $\S$. Estet aliud.institut.de donat. ubi gloss. allegat concordantias, et haec diuersiras inpraefatis nominibus tripliciter considerari potest. Primo suppressio, extinctio, et dismembratio ualde differunr ab unionibus, annexionibus, incorporationibus, et applicationibus. Secundò verbum, dismembratio, valde differt ab omnibus aliis.

19 Unio circa incorporationem non subiicitur statutum. [Alexander Imola Consilia, Consilium 114. incip. in causa. et lite. volum.quarto, numero 19 I 20] (Consiliorum seu responsorum, 173-4).

${ }^{20}$ Tertiò aliqua ex praefatis nominibus, quae inter se consona uidentur, habent tamen aliqua dissonantiam. ldeo breuiter dicendum, quod unio nomen est generale continens sub se plures species,ueluti suppressionem, et extinctionem, tanquam requisita antecedentia. Vnde dicendo unionem in suo amplo, et potiori significatu, 
Works on canon law pertaining to the union of churches and benefices were collected and summarised, among others, in Nicolaus Thilen's doctoral dissertation titled De unionibus ecclesiarum atque beneficiorum, which he defended at the University of Frankfurt am Main in 1671. ${ }^{21}$ Thilen defined the union of churches as ${ }^{22}$ an act (an activity), by which two or more separate churches or ecclesiastical benefices are connected (connectuntur) by one who has the right to unite (iure uniendi gaudet), due to advantage or urgent necessity. ${ }^{23} \mathrm{He}$ defined the resulting legal status or union as "the union of two or more benefices" (duarum pluriumve etc. Facta connexio).

Nicolaus Thilen presented a classification of unions. First, they were divided into perpetual and temporal unions (uniones perpetuas et temporales) as well as real and personal (uniones reales et personales). ${ }^{24}$ Perpetual unions are valid indefinitely (sine praefinitione temporis perdurent). However, temporal unions last for a predetermined period of time (ad certum tempus). Typically, this concerned lifelong unions, i.e. such where the authority of a particular church or the title to a given benefice was conferred onto a particular person for the duration of his life.

The personal union of churches consisted in creating only a personal bond between the united bishoprics. It was terminated with the death of a given person, i.e. a joint bishop or other beneficiary. The real union, however, bound churches as legal entities and existed as long as the churches themselves (Illa vero, quae ipsam, cui unio facta est Ecclesiam, atque quamdiu haec subsistit, durat). ${ }^{25}$ By nature, the real union was perpetual. In the ordinary gloss to Corpus iuris canonici, Thilen treated the above-mentioned

intelligimus etiam suppressionem, et extinctionem tanquam antecedentia seu praeambula ad unionem perficiendam, ut in 1. ad rem mobilem. ff. de procuratoribus, et in 1.oratio. ff. de sponsalib. et potest etiam dici, quod non sint inter se, ut genus, \& species, sed ut totum, \& n. pars, prout dicimus de domo, et partibus. Vel potest dici, quod unio illas contineat tanquam accessorias, et in consequentiam . Nam si fit unio in suo potiori significatu nempe in 1. uel 2. modo supra assignatis, praesupponitur, quod supprimatur, et extinguatur primum beneficium, et illius denominatio, cum illud, quod unitur, summat natura millius, cui sit unio, prout declarant Innocencius in d. c. primo, ne sede vacante, in fi.tertii modi, et hoc modo species seu membrare qui sit a unioni erunt annexio, applicatio, subiectio, et incorporatio, et ista inter se ualde differunt. Nam annexio, et applicatio minus operantur, quam subiectio, nam (ut praedicti scribentes declarant) potest fieri unio, applicatio seu annexio, \& tamen non aderit subiectio, quia quodlibet beneficium, sive quaelibet dignitas, vel ecclesia retinebit sua iura, et suas praeminentias, uidelicet quandounio fit tertio modo supra relato. Sed text.in capitulo Sicut unire. de excessibus praelat. post principium ponit [p. 115 B] pro eodem unionem, et subiectionem, et similiter annexio, et unio pro eodem ponuntur per Bald. et Fely. in capitulo translato. de constit. Tamen incorporation omnia penitus complectitur: quia tunc est unum tantum corpus, et unum de altero efficitur, utinquit Bar. in 1. siconuenerit, secunda, in $\S$. Si nuda ff. de pignorat. actio. Baldus et Fely. ubi supra, et pulchre Alexan. in consilio 114. incip.in causa, et lite.uolum. quarto, numero 19. et 20. ex quibus sequitur, quod praefata uerba compraehendunt omnes modos, et species, seu qualitates unionis, et propterea tot uerba fuerunt inuenta in hac materia unionis, ne esset locus alicui disputationi, et ideo praefatis uerbis omnibus vsus est tex.in regu. 12. Cancellariae de reuoc. unionum, quae non sunt sortitae effectum. Lllud autem uerbum dismembratio, potest duobus modis intelligi, uno de beneficiis, qua: alteri uniuntur, et sic prius dismembrantur, uel secondo modo potest intelligi de dissolution unionum, in qua quidem eadem iura seruari debent, quae in unionibus, ut inquit Caccialup. in dicto tract. unionum. in nono artículo.

${ }^{21}$ Disputatio inauguralis de unionibus.

22 Ibid., 9. Institutiones Iuris Canonici. § 1.

${ }^{23}[. .$.$] actus, quo duae pluresve ecclesiae vel ecclesiastica beneficia a se invicem separata, ab eo qui$ iure uniendi gaudet, ob evidens quoddam commodum vel necessitate urgentem, connectuntur [p. 9]. The act of union resulted in the formation of duarum pluriumve facta connexio [...].

${ }^{24}$ Disputatio inauguralis de unionibus, 9.

${ }^{25}$ Vide supra Praxis Beneficiorum D. Petri Rebuffi. 
three ways (modi) of forming a union as separate types (species) of church union. The classification of church unions into personal and real was known to Pierre Rebuffi, who was of the opinion that in case of doubt the existence of a real and perpetual union should be presumed. ${ }^{26}$

The findings of medieval and modern studies in canon law in the area of union of churches and benefices were collected and summarised in the work by Anaclet Reiffenstuel (1641-1703) entitled Ius canonicum universum..$^{27}$ According to this author, the union of benefices, and therefore also the union of churches, is a certain type of dissolution (quaedam suppressionis species). He defined the union itself as the amalgamation of benefices (annexio) made by the bishop or another authorized superior (quid sit beneficium ab episcopo, vel alio legitimo superior facta annexio). He classified unions similarly to the earlier authors, dividing them into temporal and perpetual unions. $\mathrm{He}$ distinguished three types of union, based on how the union was formed.

The first is unio extinctiva seu translativa, in other words a "terminating union" or "transferring union". This did not concern one church joining another, but creating a new church from two, by way of merging them. ${ }^{28} \mathrm{~A}$ new church was formed in this way (ex quod ex duabus ecclesiis fiat una ecclesia). Dictionnaire de Droit Canonique by a lawyer for the parliament in Aix, Pierre-Toussaint Durand de Maillane, which was released around the same time, stated expressis verbis that such a merger created a new legal body (corpus). ${ }^{29}$ The second type of union, referred to as an "ancillary union"; (unio accessoria), consisted in the subordination of one church to another, so that one became higher (superior) and the other lower (inferior), treated as belonging (accessorium) to the first. The first acted as the mother church, the second as the daughter. According to Reiffenstuel, a suitable vicar should be appointed in such an ancillary church (ecclesia accessoria). ${ }^{30}$ Finally, the third type of union mentioned by Reifenstuel and many other authors is unio aeque principalis ("the equally principal union"). This consisted in uniting churches by means of a bishop or other superior while each of the churches retained their current status and title. ${ }^{31}$ There was no relationship of dependency between the united churches or benefices, nor did they form a separate legal entity (corpus). ${ }^{32}$

${ }^{26}$ In dubio praesumitur facta contemplatione ecclesiae, quia ecclesiae magis ferendum est quam ersonae. Arg. cap. requisiti, de testam. Cited by: Durand de Maillane, Dictionnaire, 510.

27 Ius canonicum universum... Anacleto Reiffensuel, 222 (Lib. III. Tit. Ut ecclesiastica beneficia sin, etc. $\S$ De unione beneficiorum et conditionibus ad eam requisitis).

28 "Primus modus est, cum mediante unione ex duobus beneficiis [ecclesiis] sit unum: ita videlicet, ut neutrum eorum uniatur alteri, sed ambo simul uniantur." (Ius canonicum universum... Anacleto Reiffensuel, 223).

${ }^{29}$ Cf. “... deux eglises ou benefices on n'en fait qu'un, [...] de manière qu'ils ne fassent tous qu'un corps". Durand de Maillane, Dictionnaire de Droit Canonique, 509.

30 "Alter modus [...] quando duae ecclesiae ita uniuntur, ut non coalescant in unum corpus, sed una sit superior, alia inferior et accessoria alteri. Et tunc in Ecclesia unita, seu alteri accessoria, debet poni idoneus vicarius". Ius canonicum universum... Anacleto Reiffensuel, 223, n. 42.

31 "Tertius modus uniendi beneficia est, quando neutra ecclesia alteri subiicitur, nec ipsae simul coguntur in unum corpus, sed ambae ecclesiae suum titulum, atque honoris gradum retinent, ac proinde uniuntur aeque principaliter, ita videlicet ut rector unius sit etiam rector alterius". Ius canonicum universum... Anacleto Reiffensuel, 48, n. 51.

32 Ibid. See. also: Durand de Maillane, Dictionnaire de Droit Canonique, 510. 
The three types of union of churches and benefices presented above, distinguished by the manner in which the union was formed, were adopted into the 1917 Code of Canon Law. They are mentioned in canons 1419 et seq. devoted to church benefices. In particular, canons 1419 and 1420 list the three indicated unions of benefices, namely: 1) unio exstinctiva, 2) unio aeque principalis, 3) unio minus principalis, defining each of them. These definitions are significant and it is worth quoting each of them in extenso:

Can. 1419. Unio beneficiorum est:

$1^{\circ}$ Exstinctiva, cum aut ex suppressis duobus vel pluribus beneficiis novum atque unicum beneficium efficitur, aut unum ve1 plura ita alii uniuntur ut esse desinant;

$2^{\circ}$ Aeque principalis, cum unita beneficia remanent prout sunt, neque alterum alteri subiicitur;

$3^{\circ}$ Minus principalis, seu per subiectionem vel accessionem, cum beneficia remanent, sed unum aut plura alii tanquam accessorium principali subiiciuntur. ${ }^{33}$

Can. 1420. §1. In unione exstinctiva, beneficio quod emergit aut remanet, omnia iura et onera exstinctorum competunt, et, si inter se componi nequeant, meliora ac favorabiliora.

$\S 2$. In aeque principali, quodlibet beneficium conservat suam naturam, iura et onera, sed, vi peractae unionis, uni eidemque clerico unitorum beneficiorum tituli conferri debent.

$\S 3$. In minus principali, beneficium accessorium sequitur principale, ita ut clericus, qui principale obtinet, eo ipso et accessorium consequatur atque utriusque onera implore debeat. ${ }^{34}$

[Canon 1419. The union of benefices is:

$1^{\circ}$ 'terminating' when, from two or more dissolved benefices, a new one is formed or when one or more benefices are attached to another in such a way that they cease to exist;

$2^{\circ}$. 'equally principal', when the united benefices remain as they are and none of them is subordinate to the other;

$3^{\circ}$ 'less principal' or 'by subordination or accession' when the benefices remain, but one or more are subordinate as ancillary to another, principal benefice.

Canon 1420

$\S 1$. In the 'terminating' union (exstinctiva), all rights and liabilities of the terminated benefices pass onto the benefice which was formed or which remained, unless the best and most beneficial [rights and liabilities] can be arranged for them.

$\S 2$. In the 'equally principal' union (aeque principalis), each of the benefices retains its nature, rights and liabilities; however, following the union, the titles to the united benefices should be given to one and the same clergyman.

$\S 3$. In the 'less principal' union (minus principalis) or union 'by subordination or accession' (per subiectionem vel accessionem), the ancillary benefice is accessory to the principal benefice in such a way that the clergyman who receives the principal benefice also receives the ancillary benefice and is responsible for both.]

The canonists drew attention to the importance of the terms used in the documents of union. In fact, the type and legal effects of the union of churches or benefices depended on the terms used. In particular, Nicolaus Thilen ${ }^{35} \mathrm{drew}$ attention to the need to determine whether the union was concluded by accessorie, i.e. by subordinating one church to another, or by way of equality (aeque principaliter). If the document contained the words: quod uniat unum alteri vel incorporamus, it meant a union formed by accessorie (unio accessorie facta). But if the document stated unire tale et tale beneficium, the union was

\footnotetext{
33 Cited according to Codex Iuris Canonici, 415.

34 Ibid.

35 In 1671 he obtained the title of doctor of law in Strasbourg. See: Jöcher, Allgemeines Gelehrten, 1136.
} 
concluded aeque principaliter. This scholar, however, stipulated that in relation to the legal formulas used, local custom was also decisive (nisi ex consuetudine locorum aliud servaretur, quae optima erit interpres). ${ }^{36}$

Moreover, in the Middle Ages, as well as in modern times, the provisions of canon law on the unions of churches and benefices have been used to assess and resolve the legal problems of unions of kingdoms and other states. This is supported by the legal work of the Catalan canonist Tomas Mieres (1400-1474) entitled Apparatus super constitutionibus curiarum generalium Cathaloniae. ${ }^{37}$ When discussing the unions concluded between such states as the Principality of Catalonia, the County of Barcelona and the Kingdom of Majorca, the author also cited the provisions of canon law. ${ }^{38}$

2019 marks the 450th anniversary of the union concluded on July 1, 1569 in Lublin, as a result of which the Kingdom of Poland, referred to as the Crown, united with the Grand Duchy of Lithuania. ${ }^{39}$ The above remarks on unions in the medieval canon law are important for a more comprehensive description of the nature of this relationship, which, in my view, historical writings present in different ways, which are often far removed from legal precision. Typically, researchers describe this relationship by referring to modern or even contemporary legal concepts such as confederation, federation, parliamentary union, real union or parliamentary union, without being fully aware of what these terms actually mean. There is an abundance of historical writings on the Polish-Lithuanian union. Historians and historians of law have written on this subject for almost 150 years. It is surprising that no one has drawn on the doctrine of medieval canon law to undertake an analysis of the union of Poland and Lithuania, beginning with the first of them, i.e. the union concluded in 1385 in Krewo. ${ }^{40}$ Contrary to the opinion of historians, I believe that this act did not lead to the incorporation of Lithuania and Ruthenia into Poland, but to the formation of the union of the Kingdom of Poland and the Grand Duchy of Lithuania as two separate states under the same ruler. The union thus established reflected the character of an equally principal union (aeque principaliter), known in canon law. It was not an ordinary personal union, as this relationship was to be lasting and perpetual. Hence, it was a real union. The joint entity exercising power in both countries was to be the Crown of the Kingdom of Poland (Corona Regni Poloniae), understood as the office of the Polish king, not the Polish state. It was by no means an incorporation of the Lithuanian-Ruthenian lands into the Kingdom, but only subordinating them to the power of the Polish Crown, i.e. the Polish king, while the Grand Duchy maintained its own identity and position. The essence of this connection, well known from the Iberian Peninsula in the fifteenth century, is reflected in the adage: Unio regnorum sub una Corona non causat e orum unitatem. ${ }^{41}$

${ }^{36}$ Disputatio inauguralis de unionibus, 11.

${ }^{37}$ Apparatus super constitutionibus [...] per Thomam Mieres [...].

${ }^{38}$ Cf. e.g. "Propter unionem fit communication idiomatum et privilegiorum, acurium, vide glos. in cap. infra. Extra. Ne sede vacante aliquid innovetur". Ibid., 146.

${ }^{39}$ Frost, The Oxford History, passim. See aussi: Gloël, "La monarquias", passim.

${ }^{40}$ Błaszczyk, "Czy była unia krewska", 3-96; Kiaupienè, "Akt krewski”, 47-62;Kiaupienè, "1385 metai, Kreva", 39-68.

${ }^{41}$ De Luca Venusini, Theatrum Veritatis, 200. The author of this work, Johannes Baptista De Luca Venusinus (1614-1683) was a cardinal-presbyter of the Holy Roman Church. 
This model changed in 1413, when the Union of Horodlo was concluded. This union introduced a significant qualitative change in the relations between the Kingdom of Poland and the Grand Duchy of Lithuania. Both countries maintained their separateness, but they were in a legal bond which can be defined per analogiam to canon law in terms of the union per subiectionem, This meant that the Grand Duchy was a separate state with its own identity under the sui generis power of the great prince like a sui generis vicar of the Polish king. This was because the act of the Union of Horodlo provided that the direct power in Lithuania would be exercised by the Grand Duke Witold Kiejstutowicz. At the same time, King of Poland Władysław Jagiełło retained his supremacy over the Grand Duchy as the hereditary supreme prince (dux supremus). Rules for the succession to the throne in Lithuania were also established. The election of Witold's successor by the grand ducal council was to take place with the consent of the king and the council of the Kingdom of Poland..$^{42}$ The relationship between the Polish Crown and the Grand Duchy was not, in essence, a feudal relationship, but a peculiar relationship of the union of the two states, in essence a relationship based on the model of the church union per subiectionem seu accessionem. This observation is based only on the analogy of the position of both Polish and Lithuanian rulers to the relationship between the titular bishop of both dioceses and his vicar managing the diocese - dauther.

The union of the Kingdom of Poland and the Grand Duchy of Lithuania, initiated in Krewo in 1385, found its finale in the Lublin Sejm of 1569 in the form of uniting the two states into "one inseparable and indistinct body, as well as an indistinct but one and common Rzeczpospolita (Respublica), which united and bonded two states and nations into one people." [Act of Union, Art. 3]. ${ }^{43}$ In legal terms, the union consisted in combining the two states into one legal entity, referred to as Rzeczpospolita, remaining under one common sovereign power in the form of the king and the general sejm (parliament). In practice, it was the model of uniting two legal entities into a new one, used in the Church. In legal terms, the structure resembled the union of churches known as unio per extinctionem, i.e. one where the former two churches or benefices lose their legal status due to the unification, and in their place a new legal entity is created. ${ }^{44}$ Legally, the union of Poland and Lithuania formed as a result of the Lublin Union was a single state, which maintained a number of political and legal differences in their internal relations, in particular separate judicial laws. These differences did not invalidate the unity of the state, but at the most showed its complex character (civitas composita). This was undoubtedly emphasized in the document issued by King Zygmunt August at the Lublin Sejm of March 24, 1569:

With this only exception that, as in one indistinct and inseparable body, every part and every limb has its own function and purpose, so in this one Rzeczpospolita, the Polish and Lithuanian nations have certain judiciary customs, rights and privileges, and their own separate courts-of-law, which however do not, nor will they ever, hinder this oneness or this union, because they will not cause a division or disconnection of this community. ${ }^{45}$

${ }^{42}$ Frost, The Oxford History.

${ }^{43}$ Kutrzeba and Semkowicz, Akta unii Polski z Litwa, no. 148, 343; no. 149, 358.

${ }^{44}$ See: Uruszczak, Unio regnorum. I presented the above analysis of the Lublin Union in my work: Uruszczak, "Zasada parlamentaryzmu", 50-1.

${ }^{45}$ Kutrzeba and Semkowicz, Akta unii Polski z Litwa, no. 115, 223-4. 
In my view, it is incorrect to describe the Lublin Union as a real union. Such a union would take place if, after the conclusion of the Union of Lublin, both the Polish Kingdom and the Grand Duchy retained their sovereign powers and remained as separate entities on the international forum. The Rzeczpospolita, however, as a new state was one country, in which none of its constituent parts retained its own sovereign local authority. However, sovereignty remained at the level of political nations, i.e. the crown nobility and Lithuanian nobility. Claims denying that the Rzeczpospolita was a state and recognizing it as a confederation type or a community-of-sovereign-states type of union are misguided. There is no doubt that the Rzeczpospolita fulfilled all the conceptual criteria of a state, although it was not an absolute monarchy, and its sovereignty was in the hands of a political nation, i.e. the nobility. 
ANEXUS - Unions of churches in old canon law (source: author's own compilation)

UNIO AEQUE PRINCIPALIS

Terminology: annexio, applicatio

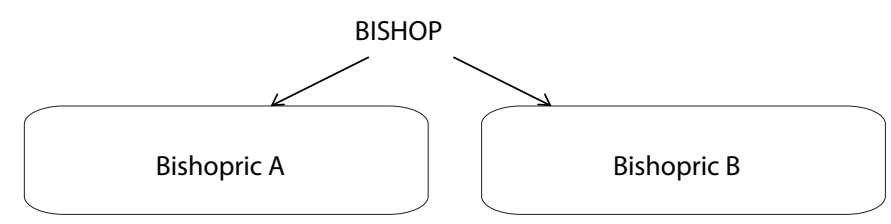

Figure 1. Unio aeque principalis

UNIO PER SUBIECTIONEM SEU ACCESSIONEM

Terminology: accessio, incorporatio, subordinatio

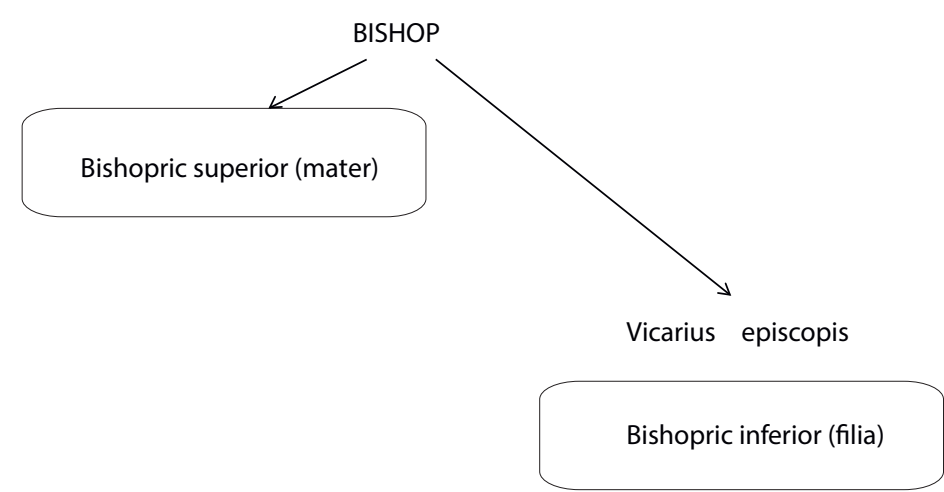

Figure 2. Unio per subiectionem seu accessionem 
UNIO PER EXTINCTIONEM SEU TRANSLATIONEM

Terminology: extinctio, translatio

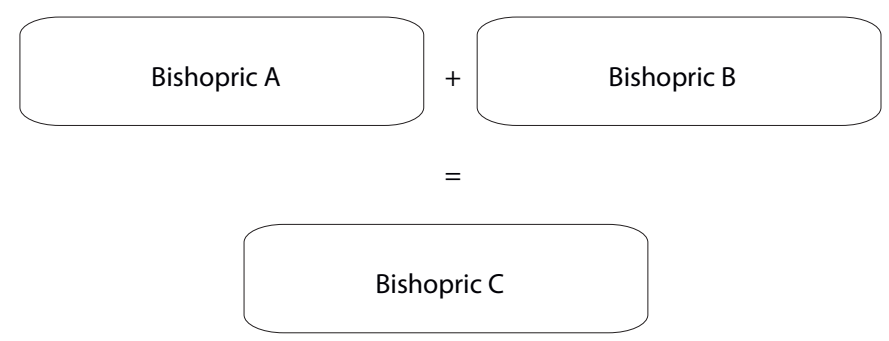

Figure 3. Unio per extinctionem seu translationem

\section{Bibliography}

\section{Primary sources and old prints}

[Cacialupus, Johannes Baptista] De unionibus ecclesiarum et beneficiorum tractatus mire utilis Cacialupi iurisc. eximii. Romiae: Apud F. Minitium Calvuum, Anno MDXXI [1521], Mense Iulio.

Alphonsi Hoieda de Mendoca Carmonensis collegii Sanctae Mariae de Iesu, et universitatis Hispalensis Collegae, Catedrae primariae dictae universitatis Iuris Pontificii Regentis de Beneficiorum incomptibilitate atque compatibilitate tractatus. In cuius parte prima de variis incompatibilitatum speciebus agitur. In secunda autem causus omnes, in quibus multa beneficia in persona unius beneficiarii sunt compatibilia traduntur. Cum indice locorumve insigniu appositissimo. Cum privilegiis. Venetiis: Apud Ioannem Variscum, et Socios, MDLXXIX [1579].

Apparatus super constitutionibus curiarum generaliom Cathaloniae per Thomam Mieres in Decretis licentiatum et iurisperitum Gerundensem editi pars secunda... Barcinoniae: Typis et aere Sebastiani à Cormellas, Anno MDCXXI [1621].

Codex Iuris Canonici Pii X Pontificis Maximi ius sudigestus Benedicti Papae XV auctoritate promulgatus. Romae: Typis Polyglottis Vaticanis, 1918.

Consiliorum seu responsorum Alexandri Tartagni Imolensis..., Lib. IV. Francoforti ad Moenum: Sumptibus Lazari Zetzneri, 1610.

De Luca Venusini, Johannes Baptista, S.R.E. Presbyteri Cardinalis. Theatrum Veritatis et Justitiae sive decisivi discursus per materias, seu titulos distincti, et ad veritatem editi in forensibus 
controversiis canonicis et civilibus in quibus in Urbe Advocatus pro una partium scripsit, vel consultus respondit, Liber secundus De regalibus [...]. Venetiis: Ex Typographia Balleoniana, 1726.

Decretales Gregorii Papae IX suae integritati una cum glossis restituae. Venetiis: [s.e.], 1591.

Decretum Gratiani emendatum et notationibus illustratus una cum glossis Gregorii XIII Pont. Max. Iussu editum ad exemplar Romanum diligenter recognitum. Lugduni: [s.e.], MDLXXXIIII [1584].

Disputatio inauguralis de unionibus ecclesiarum atque beneficiorum ecclesiasticorum quam praeside divino numine ex decreto magnifici et amplissimi dictorum ordinis in florentissima argentoratensium universitate pro licentia summos in utroque iure honores et privilegia doctoralia rite consequendi, solenni eruditorum examinisistit Nicolaus Thilen Moeno-Francofurtanus, die septembris Argentorati. M. wyd.: Exprimebat Johannes Wilhelmus Tidemann, Anno MDCLXXI, Strasburg [1671].

Durand de Maillane, Pierre-Toussaint. Dictionnaire de Droit Canonique et de pratique bénéficiale. 3ème éd., tome Ve. Lyon: Chez Joseph Duplain, 1776.

Henrici a Segusio Cardinalis Hostiensis Aurea Summa... Lib. III. Coloniae: Sumptibus Lazari Zetzneri Bibliopolae, MDCXII [1612].

Ius canonicum universum clara methodo juxta titutlos quinque librorum decretalium [...] authore R.P.F. Anacleto Reiffensuel [...] Editio Novissima, cui accessit tractatus de regulis iuris cum repertorio generali totius operis. Tomus tertius. Antverpiae: Sumptibius Societatis, MDCCLV [1755].

Jöcher, Christian Gottlieb. Allgemeines Gelehrten-LEXICON: Darinne die Gelehrten aller Stände sowohl männ-als weiblichen Geschlechts, welche vom Anfange der Welt bis auf ietzige Zeit gelebt, und sich der gelehrten Welt bekannt gemacht, Nach ihrer Geburt, Leben, merckwürdigen Geschichten, Absterben und Schrifften aus den glaubwürdigsten Scribenten in alphabetischer Ordnung beschrieben werden. S-Z. Vierter Theil. Leipzig: Johann Friedrich Gleditsch Verlag und Buchhandlung, 1751.

Kutrzeba, Stanisław and Semkowicz, Władysław. Akta unii Polski z Litwa 1385-1791 [PolishLithuanian union acts 1385-1791]. Kraków: Polska Akademia Umiejętności [Polish Academy of Arts and Sciences] and Towarzystwo Naukowe Warszawskie [Warsaw Scientific Society], 1932.

Praxis Beneficiorum D. Petri Rebuff [...]: Cui Apposuimus Bullam Coenae Domini, Bullam Item Ieiuniorum Ac Supplicationum S.D.N.P. Pauli III. Editio vltima multò quam antehac auctior [et] emendatior [...]. Lugduni: Apud haeredes Gulielmi Rouillii, 1599.

\section{Secondary sources}

Błaszczyk, Grzegorz. „Czy była unia krewska?”. Kwartalnik Historyczny 100, no. 1 (2003): 8396.

De Dios, Salustiano. "La doctrina sobre el poder del príncipe en Alfonso Hojeda de Mendoza. Alfonso Hojeda de Mendoza's doctrine on the prince's power". Studia Historica: Historia Moderna 21 (1999): 241-70. Accessed June, 5, 2020, https://revistas.usal.es/index.php/Studia_Historica/article/view/4853/4892.

Frost, Robert. The Oxford History of Poland-Lithuania, Volume I: The Making of Polish-Lithuanian Union, 1385-1569. Oxford: Oxford University Press, 2015.

Gloël, Matthias. "La monarquias compuestas en la época moderna: Concepta y ejemplos" [The Early Moderne composite monarchies. Concept and Exemples], Universum 29, no. 2 Talca. dic. (2014): 83-97. 
Herman, Franjo. "Sjedinjenje biskupija Bosansko-Dakovacke i Srijemske (De unione dioecesium Bosnensis seu Diacovensis et Sirmensis)”. Bogoslovska Smotra 6, (1941): 81-115.

Hinschius, Paul. System des katholischen Kirchenrechts. Bd. 2. Berlin: Verlag von I. Guttentag (D. Collin), 1878.

Hofmeister, Philipp. "Die Doppeltitel der Bischöfe". Zeitschrift der Savigny-Stiftung für Rechtsgeschichte: Kanonistische Abteilung, 34 (1947): 172-252.

Kiaupienè, Jūratè. "1385 metai, Kreva: pasikly-dę tarp tikroves ir mito”. In 1385 m. rugpjućio 14 d. Krevos aktas, ed. by Jūratė Kiaupienè, 39-68. Vilnius: Žara, 2002.

Kiaupienè, Jūratè. „Akt krewski z 14 sierpnia 1385 r. Gdzie kryje się problem — w dokumencie czy w jego interpretacjach?" Transl. by Aleksandra Rodziňska-Chojnowska, Kwartalnik Historyczny 108, no. 4 (2001): 47-62.

Knibbs, Eric. Ansgar, Rimbert and the Forged Foundations of Hamburg-Bremen, Church, Faith and Culture in the Medieval West. Farnham: Ashgate Publishing Limited, 2011.

Lindner, Dominikus. Die Lehre der Inkorporation in ihrer geschichtlichen Entwicklung. München: Max Hueber Verlag, 1951.

Scholz, Klaus. Das Bistum Münster. 6. Das Stift alter Dom St. Pauli in Münster. Berlin-New York: Walter de Gruyter, 1995 (Germania Sacra. Historisch-Statistische Beschreibung der Kirche des Alten Reiches, Hgg. Vom Max-Planck-Institut für Geschichte, Redaktion Irener Crusius. Neue Folge 53. Die Bistümer der Kirchenprovinz Köln).

Schulte, Johann Friedrich. von. Die Geschichte der Quellen und Literatur des Canonischen Rechts von Gratian bis auf die Gegenwart. Bd. 1-2. Stuttgart: Enke, 1875-7.

Uruszczak, Wacław. "Zasada parlamentaryzmu na tle zasad ustrojowych dawnego państwa polskiego" [The principle of parliamentarism against the background of the political system of the old Polish state]. In Sejm Królestwa Polskiego i Rzeczypospolitej Obojga Narodów a europejskie reprezentacje stanowe [The Sejm of the Kingdom of Poland and the Polish-Lithuanian Commonwealth and European state representations], ed. by Dariusz Kupisz and Wacław Uruszczak, 39-60. Warszawa: Wydawnictwo Sejmowe, 2019.

Uruszczak, Wacław. Unio regnorum sub una Corona non causat eorum unitatem. Unia Polski $i$ Litwy w Krewie w 1385 r. Studium historyczno-prawne [The Union of Poland and Lithuania in Krewo in 1385. Historical and legal study]. Kraków: Uniwersytet Jagielloński, Katedra Historii Prawa Polskiego, 2017. Accessed August 31, 2020, http://www.khpp.wpia.uj.edu.pl/ documents/106750129/0/unia_polski_i_litwy_v3/a46ba21f-340d-411f-8c67-962e0e9c90a1. 